\title{
ANALISIS SISTEM ADMINISTRASI PERPAJAKAN MODERN TERHADAP EFEKTIVITAS PELAKSANAAN PEMERIKSAAN FUNGSIONAL DAN IMPLIKASINYA PADA KEPATUHAN WAJIB PAJAK (Studi Kasus pada KPP Pratama Bireuen)
}

\author{
Razif $^{1}$, Rahmawati $^{2}$ \\ ${ }^{1,2}$ Prodi Akuntansi Fakultas Ekonomi dan Bisnis Universitas Malikussaleh Lhokseumawe \\ razif@unimal.ac.id
}

\begin{abstract}
This study aimed to determine the analysis of the modern tax administration system on the effectiveness of the implementation of functional examinations and their implications for taxpayer compliance at KPP Pratama Bireun. The data used in this study came from direct interviews. The population in this study amounted to 5 functional positions. The analytical method used was descriptive qualitative. The results indicated that the modern tax administration system at KPP Pratama Bireun was in good classification, and also the preparation of inspection programs capable in reducing difficulties on the implementation of tax audits.
\end{abstract}

Keywords: Modern Tax Administration System, the effectiveness of Implementing Functional checks, Tax Compliance.

\section{PENDAHULUAN}

Pajak merupakan sumber utama penerimaan negara yang digunakan untuk membiayai pengeluaran rutin maupun pembangunan agar tercapai kemakmuran dan kesejahteraan masyarakat. Hal tersebut tertuang dalam Anggaran Penerimaan dan Belanja Negara (APBN) dimana penerimaan pajak merupakan penerimaan dalam negeri yang terbesar. Pajak adalah iuran rakyat kepada kas negara berdasarkan undang-undang (yang dapat dipaksakan) dengan tidak mendapat jasa timbal (kontraprestasi) yang langsung dapat ditunjukkan dan yang dipergunakan untuk membayar pengeluaran umum (Mardiasmo, 2011:1). Oleh karena itu, semua rakyat yang menurut undangundang termasuk sebagai wajib pajak harus membayar pajak sesuai dengan kewajibannya (Suminarsasi, 2011).

Pajak berperan dalam mengatur sumbersumber ekonomi, alokasi, distribusi dan stabilisasi. Pajak merupakan sumber penerimaan utama yang merefleksikan praktek demokrasi yang paling mendasar, dan merupakan

perwujudan peran serta rakyat dalam membiayai Negara dan Pemerintahannya.
Jadi Ditjen Pajak hanya bertugas mengawasi dan memberikan sanksi kepada wajib pajak yang tidak mematuhi ketentuanketentuan perpajakan. Oleh karena itu, sistem ini akan berjalan dengan baik apabila masyarakat memiliki tingkat kesadaran perpajakan secara suka rela (voluntary tax compliance) yang tinggi (suminarsasi,2011). Hal tersebut menjadi kendala dari sistem perpajakan Indonesia pada saat ini.

Kepatuhan wajib pajak mencakup usahausaha untuk memenuhi kewajiban administrasi perpajakan dengan cara menghitung pajak secara benar, sesuai dengan ketentuan perpajakan, kepatuhan dalam membayar dan melaporkan tepat waktu sesuai dengan deadline pembayaran dan pelaporan pajak yang telah ditetapkan (Pohan, 2016:15).

Peningkatan penerimaan pajak masih belum diimbangi dengan peningkatan kepatuhan pajak di Indonesia. Fakta di Indonesia menunjukkan tingkat kepatuhan pajak masih rendah (Jatmiko dalam D.Martani, 2012). Pada hakikatnya kepatuhan wajib pajak dipengaruhi oleh kondisi sistem administrasi perpajakan. Perbaikan administrasi perpajakan sendiri 
diharapkan dapat mendorong kepatuhan Wajib Pajak. Berdasarkan uraian di atas, dapat dikatakan bahwa tingkat kepatuhan Wajib Pajak dipengaruhi oleh bagaimana administrasi perpajakan dilakukan.

Sistem administrasi perpajakan modern adalah penyempurnaan atau perbaikan kinerja admnistrasi baik secara individu, kelompok, maupun kelembagaan agar lebih efisien, ekonomis dan cepat (Suparman, 2007:1). Adapun jiwa dari program modernisasi ini adalah pelaksanaan good governance, yaitu penerapan sistem administrasi perpajakan yang transparan dan akuntabel, dengan memanfaatkan sistem informasi teknologi yang handal dan terkini. Strategi yang ditempuh adalah pemberian pelayanan prima sekaligus pengawasan intensif kepada para wajib pajak. Good governance biasanya dikaitkan dengan mekanisme pengawasan internal (internal control) yang bertujuan untuk meminimalkan terjadinya penyimpangan ataupun penyelewengan dalam organisasi, baik itu dilakukan oleh pegawai maupun pihak lainnya, baik disengaja maupun tidak. Apabila sistem perpajakan telah dilaksanakan dengan baik, maka pelaksanaan pemeriksaan akan berjalan sesuai dengan jangka waktu dan tahapan pemeriksaan akan terpenuhi.

Salah satu upaya yang dilakukan oleh pemerintah untuk meningkatkan penerimaan negara dari sektor pajak adalah dengan melakukan tax reform, yaitu dengan melakukan reformasi terhadap Peraturan Perundang-Undangan Perpajakan serta sistem administrasi perpajakan, agar basis pajak dapat semakin diperluas, sehingga potensi penerimaan pajak yang tersedia dapat dipungut secara optimal dengan menjunjung asas keadilan sosial dan memberikan pelayanan prima kepada Wajib Pajak (Widjaya, 2011).

Pada official assessment system, besarnya pajak terutang Wajib Pajak ditentukan sepenuhnya oleh fiskus selaku pemungut pajak, sedangkan self assessment system adalah suatu sistem perpajakan yang memberi kepercayaan kepada Wajib Pajak untuk memenuhi dan melaksanakan sendiri kewajiban dan hak per pajakannya. Hal ini tentu saja memberikan $\mathrm{k}$ emudahan bagi Wajib Pajak dalam menguru s masalah pajak (www.infopajak.com).

Pemeriksaan pajak adalah untuk meningkatkan kepatuhan (tax compliance), melalui upaya-upaya penegakan hukum (law enforcement), sehingga dapat meningkatkan penerimaan pajak (Suandy 2006: 100 ).

Penerimaan pajak yang setiap tahun terus meningkat, ternyata tidak lepas dari masalah seperti SPT lebih bayar, maka petugas pemeriksaan akan melakukan pemeriksaan terhadap Wajib Pajak guna meningkatkan kepatuhan Wajib Pajak. Contoh yang cukup jelas adalah Wajib Pajak menyampaikan SPT dengan melampirkan informasi laporan keuangan yang tidak sesuai dengan kondisi keuangannya. Penyampaian SPT lebih bayar diakibatkan oleh kurangnya ketelitian atau kesalahan dalam mengisi SPT yang telah diisi oleh Wajib Pajak guna menentukan pajak yang harus dibayarnya.

Fakta di Indonesia setiap tahun muncul basis pemajakan yang akan terus bertambah seiring Kinerja Ditjen Pajak dalam kegiatan ekstensifikasi dan pengawasan. Sebagai contoh, wajib pajak badan atau pengusaha yang mengikuti program amnesti pajak secara otomatis akan menjadi basis pemajakan baru. Karena, dengan mengikuti amnesti pajak, berarti secara tidak langsung wajib pajak mengakui kekeliruan dalam menghitung kemampuan finansialnya. Mereka ini akan menjadi pembayar pajak baru atau membayar pajak lebih besar pada tahun berikutnya. Sehingga, basis pemajakan akan menjadi lebih luas, baik secara kuantitas maupun kualitasnya.

Administrasi perpajakan di Indonesia masih perlu diperbaiki, dengan perbaikan diharapkan Wajib Pajak lebih termotivasi dalam memenuhi kewajiban perpajakannya. Administrasi yang baik adalah instansi pajak, sumber daya aparat pajak, dan 
prosedur perpajakan yang baik. Dengan kondisi tersebut maka usaha memberikan pelayanan bagi Wajib Pajak akan lebih baik, lebih cepat dan menyenangkan Wajib Pajak. Dampaknya akan nampak pada kerelaan Wajib Pajak untuk membayar pajak. Wajib Pajak akan patuh (karena tekanan) karena mereka berpikir adanya sanksi berat akibat tindakan ilegal dalam usahanya untuk penyelundupan pajak. Tindakan pemberian sanksi tersebut terjadi jika Wajib Pajak terdeteksi dengan administrasi yang baik dan terintegrasi serta melalui aktivitas pemeriksaan oleh aparat pajak yang berkompeten dan memiliki integrasi tinggi, melakukan tindakan tax evasion.

Penerapan self assessment system yang dianut dalam sistem perpajakan sekarang ini, dan fenomena masyarakat terhadap tingkat kepatuhan pajak yang rendah menuntut Direktorat Jenderal Pajak (DJP) untuk selalu melakukan pembinaan dan pengawasan terhadap Wajib Pajak. Salah satu bentuk pengawasan tersebut adalah melalui pemeriksaan. Kewenangan DJP untuk melakukan pemeriksaan tersebut diatur dalam Pasal 29 UU KUP. Pentingnya pemeriksaan pada Kantor Pelayanan Pajak (KPP) tidak lain adalah untuk meningkatkan kepatuhan Wajib Pajak, agar Wajib Pajak berada pada peraturan perundang- undangan perpajakan sehingga penyelewengan pajak yang dilakukan akan mudah diatasi oleh pihak pajak. Dalam hal ini, Direktorat Jenderal Pajak mempunyai kewenangan melakukan pemeriksaan untuk menguji pemenuhan kewajiban perpajakan. Pelaksanaan pemeriksaan tersebut adalah dalam rangka melaksanakan peraturan perundang-undangan perpajakan.

Berdasarkan uraian di atas peneliti merasa tertarik untuk mengetahui lebih lanjut masalah ini dan peneliti hanya membahas mengenai Sistem Administrasi Perpa jakan Modern, sehingga peneliti tertarik untuk mengambil judul: "Analisis Sistem Administrasi Perpajakan Modern Terhadap Efektivitas Pelaksanaan
Pemeriksaan Fungsional Dan Implikasinya Pada Kepatuhan Wajib Pajak (Studi Kasus Pada Kantor Pelayanan Pajak Pratama Bireuen)" .Dari latar belakang diatas yang menjadi rumusan masalah adalah:

1. Bagaimana Analisis Sistem Administrasi Perpajakan Modern Terhadap Kepatuhan Wajib Pajak melalui Efektivitas Pelaksanaan Pemeriksaan Fungsional ( Studi Kasus pada KPP Pratama Bireun)

\section{TINJAUAN PUSTAKA}

\section{Kepatuhan Wajib Pajak}

Menurut Gunadi (2013:94) kepatuhan wajib pajak adalah wajib pajak mempunyai kesediaan untuk memenuhi perpajakannya sesuai dengan aturan yang berlaku tanpa perlu diadakan pemeriksaan, investigasi seksama, peringatan ataupun ancaman dan penerapan sanksi baik hukum maupun administrasi. Kepatuhan adalah pemenuhan kewajiban perpajakan yang dilakukan oleh wajib pajak dalam rangka memberikan kontribusi bagi pembangunan, dalam pemenuhannya diberikan secara sukarela (Oktaviani, 2015).

Berdasarkan pasal 1 Undang-Undang Nomor 16 Tahun 2000 pengertian wajib pajak adalah orang pribadi atau badan, meliputi pembayar pajak, pemotong pajak, dan pemungut pajak, yang mempunyai hak dan kewajiban perpajakan sesuai denga ketentuan perundang-undangan perpajakan.

Badan adalah sekumpulan orang atau modal yang merupakan kesatuan baik yang melakukan usaha maupun yang tidak melakukan usaha yang meliputi perseroan terbatas, perseroan komanditer, perseroan lainnya, Badan Usaha Milik Negara (BUMN) atau Badan Usaha Milik Daerah (BUMD) dengan nama dan dalam bentuk apapun, firma, kongsi, koperasi, dana pensiun, persekutuan, perkumpulan, yayasan, organisasi massa, organisasi sosial politik, atau organisasi lainnya, lembaga dan bentuk badan lainnya termasuk kontrak 
investasi kolektif dan bentuk usaha tetap. Kewajiban perpajakan Wajib Pajak badan maupun perseorangan sesuai dengan undang-undang KUP antara lain:

a. Wajib mendaftarkan diri kepada Kantor Pelayanan Pajak (KPP) terdekat untuk mendapatkan NPWP.

b. Wajib mengisi dan menyampaikan Surat Pemberitahuan (SPT) dengan benar, lengkap dan jelas.

c. Wajib membayar atau menyetor pajak yang terutang melalui Kantor Pos atau Bank persepsi yang ditunjuk.

Jadi dari definisi di atas dapat disimpulkan bahwa Wajib Pajak ini terdiri dari dua jenis yaitu Wajib Pajak Orang Pribadi dan Wajib Pajak badan yang memenuhi definisi sebagai subjek pajak dan menerima atau memperoleh penghasilan yang merupakan objek pajak yang menurut ketentuan peraturan perundang-undangan perpajakan ditentukan untuk melakukan kewajiban perpajakan, termasuk pemungut pajak atau pemotong pajak tertentu.

\section{Sistem Administrasi Perpajakan Modern}

Sistem administrasi perpajakan modern adalah penyempurnaan atau perbaikan kinerja admnistrasi baik secara individu, kelompok, maupun kelembagaan agar lebih efisien, ekonomis dan cepat (Suparman, 2007:1)

Menurut Liberti Pandiangan (2008:8) dalam Rapina, et al (2011) adapun tujuan modernisasi perpajakan adalah untuk menjawab latar belakang dilakukannya modernisasi perpajakan, yaitu:

a. Tercapainya tingkat kepatuhan pajak (tax complience) yang tinggi.

b. Tercapainya tingkat kepercayaan (trust) terhadap administrasi perpajakan yang tinggi .

c. Tercapainya tingkat produktivitas pegawai pajak yang tinggi.
Sedangkan manfaat dari program modernisasi bagi wajib pajak sebagai berikut (www.reform.depkeu.go.id):

a. Pelayanan yang lebih baik, terpadu, dan personal, melalui:

1. Konsep One Stop Service yang melayani seluruh jenis pajak (PPh, PPN \& BPHTB).

2. Adanya tenaga Account Representative (AR) dengan tugas antara lain konsultasi untuk membantu segala permasalahan Wajib Pajak (WP), mengingatkan Wajib Pajak (WP) atas pemenuhan kewajiban perpajakannya, update atas peraturan perpajakan yang terbaru.

3. Pemanfaatan IT secara maksimal: email, e-SPT, efilling dan lain-lain.

4. SDM yang professional, adanya fit and proper test dan competency mapping, pelaksanaan kode etik yang tegas dan konsisten, pemberian tunjangan khusus (peningkatan remunisasi)

5. Pemeriksaan yang lebih terbuka dan profesional dengan konsep spesialisasi.

b. Penerapan dan penegakan good governance di semua lini.

\section{Pemeriksaan Pajak}

Pemeriksaan adalah serangkaian kegiatan menghimpun dan mengolah data dan atau bukti yang dilaksanakan secara objektif dan profesional berdasarkan standar pemeriksaan untuk menguji kepatuhan pemenuhan kewajiban perpajakan dan atau untuk tujuan lain dalam rangka melaksanakan ketentuan perundang-undangan perpajakan. Direktur Jenderal Pajak berwenang melakukan pemeriksaan untuk menguji kepatuhan pemenuhan kewajiban perpajakan yang telah 
dilaksanakan atas dasar self assessment system.

\section{Hubungan Sistem Administrasi Perpajakan Modern dengan Efektivitas Pelaksanaan Pemeriksaan Rutin \\ Pelaksanaan pemeriksaan rutin} merupakan salah satu upaya untuk meningkatkan efektivitas kinerja terkait dengan sistem administrasi perpajakan modern. Rahayu (2009) menyatakan bahwa, "Sistem administrasi perpajakan modern memiliki program-program reformasi administrasi perpajakan jangka menengah DJP, diantaranya yaitu program meningkatkan efektivitas pemeriksaan". Selanjutnya, Rahayu (2009) menjelaskan:

Untuk kegiatan law enforcement, dapat dikembangkan program pemeriksaan berbasis analisis risiko (risk analysis), sehingga sumber daya yang ada dapat secara efektif melakukan pemeriksaan berdasarkan skala prioritas dengan membuat segmentasi risiko yang dihadapi. Apabila sistem perpajakan modern telah dilaksanakan dengan baik, maka pelaksanaan pemeriksaan akan efektif sesuai dengan jangka waktu, tahapan pemeriksaan yang dipenuhi, dan kualitas SDM.

Sistem administrasi perpajakan modern merupakan perwujudan dari program dan kegiatan reformasi administrasi perpajakan yang mengalami penyempurnaan atau perbaikan kinerjanya, baik secara individu, kelompok, maupun kelembagaan agar sistem administrasi tersebut lebih efisien, ekonomis dan cepat. Sistem modernisasi perpajakan dilakukan bertujuan untuk membuat Kantor Pelayanan Pajak menjadi baru, kantor unit yang baru melayani Wajib Pajak dengan kondisi yang nyaman dan aman.

\section{Penelitian Terdahulu}

Penelitian ini mengacu pada penelitian yang dilakukan oleh patsal (2012), yang dilakukan di kota Makassar dengan mengungkapkan bahwa sistem administrasi perpajakan modern berpengaruh terhadap efektivitas pelaksanaan pemeriksaan fungsional. Penelitian lain juga dilakukan oleh Misra (2013), yang dilakukan di padang dengan mengungkapkan bahwa modernisasi sistem administrasi perpajakan berpengaruh terhadap tingkat kepatuhan Pengusaha Kena Pajak. Penelitian serupa juga dilakukan oleh Aminah (2014), yang dilakukan di kota Surakarta dengan mengungkapkan bahwa struktur organisasi dan budaya organisasi berpengaruh terhadap kepatuhan wajib pajak. Penelitian ini juga dilakukan oleh Ririn (2015), yang dilakukan di surabaya dengan mengungkapkan bahwa Modernisasi sistem administrasi perpajakan berpengaruh positif dan signifikan terhadap kepatuhan wajib pajak. Penelitian ini juga pernah dilakukan oleh Erawati (2016), yang dilakukan di Denpasar Timur dengan mengungkapkan bahwa Secara simultan Sistem administrasi perpajakan modern berpengaruh positif dan tidak signifikan terhadap efektivitas pelaksanaan pemeriksaan fungsional.

\section{Kerangka Konseptual}

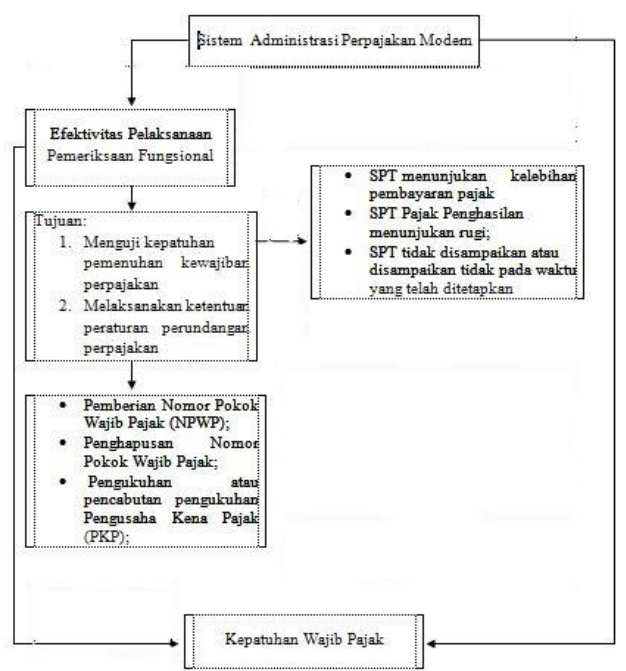

Penelitian ini berlokasi di Kantor Pelayanan Pajak Pratama Kabupaten Bireuen yang bertempat di Jl. Raya Banda Aceh-Medan, Cot Gapu, Kota Juang, 
Kabupaten Bireuen, Aceh 242, dan penelitian dilakukan pada tahun 2017 .

\section{Metodologi Penelitian}

Jenis penelitian yang digunakan peneliti adalah penelitian kualitatif deskriptif. Penelitian kualitatif deskriptif yaitu penelitian yang dilakukan untuk mengetahui nilai variabel mandiri, baik satu variabel atau lebih (Independen) tanpa membuat perbandingan atau menghubungkan antara variabel satu dengan variabel lainnya (Sugiyono, 2011:1). Penelitian kualitatif deskriptif bertujuan untuk memperoleh gambaran yang mendalam tentang Analisis Sistem Administrasi Perpajakan Modern Terhadap Kepatuhan Wajib Pajak Melalui Efektivitas Pelaksanaan Pemeriksaan Fungsional (Studi Kasus pada KPP Pratama Bireun).

\section{Informan Penelitian}

Adapun yang menjadi Informan Penelitian ini adalah :

1. Jabatan Supervisor KPP Pratama Bireun

2. Ketua Tim I KPP Pratama Bireun

3. Anggota Tim I KPP Pratama Bireun

4. Ketua Tim II KPP Pratama Bireun

5. Anggota Tim II KPP Pratama Bireun

\section{Jenis dan Sumber Data}

Adapun Data yang diperoleh dari penelitian ini yaitu :

1. Data Primer adalah data yang diperoleh langsung dari hasil wawancara dengan sumber data yaitu informan yang baik dalam permasalahan tersebut diatas.

2. Data sekunder adalah data yang diperoleh dari studi kepustakaan seperti catatan, penulisan atau pendapat ahli yang berkaitan dengan analisis sistem administrasi

$$
\begin{aligned}
& \text { perpajakan modern terhadap } \\
& \text { kepatuhan wajib pajak melalui } \\
& \text { efektivitas pelaksanaan } \\
& \text { pemeriksaan fungsional. }
\end{aligned}
$$

\section{Teknik Pengumpulan Data}

Menurut Sugiyono (2007 : 308), teknik pengumpulan data merupakan langkah yang paling utama dalam penelitian ini Karena tujuan utama dalam penelitian ini adalah mendapatkan data sesuai dengan metode penelitian diatas, maka dalam penelitian ini teknik pengumpulan data dilakukan dengan cara sebagai berikut :

\section{Wawancara}

Menurut Estrberg dalam sugiyono (2007 : 316), wawancara merupakan pertemuan dua orang untuk bertukar informasi dan ide melalui Tanya jawab, sehingga dapat dikonstruksikan makna dalam suatu topik tertentu. Berdasarkan definisi diatas, maka wawancara merupakan teknik pengumpulan data yang dilakukan melalui komunikasi langsung antara informan dan peneliti untuk mengetahui hal-hal awal mengenai masalah maupun hal-hal yang lebih mendalam peneliti melakukan wawancara yang terstruktur guna memperoleh informasi yang relevan dengan permasalahan yang ingin dipecahkan dalam penelitian ini, yaitu wawancara dengan informan-informan yang telah dipersiapkan.

2. Observasi

Menurut Nazir (2011 : 175) menyatakan bahwa pengamatan dalam metode ilmiah mempunyai kriteria sebagai berikut : (a) pengamatan digunakan untuk penelitian dan telah direncanakan secara sistematik; (b) pengamatan harus berkaitan dengan tujuan penelitian yang telah direncanakan; (c) pengamatan tersebut dicatat secara sistematis dan dihubungkan dengan proporsi umum dan bukan dipaparkan sebagai sesuatu set yang menarik perhatian saja; dan (d) pengamatan dapat di cek dan dikontrol atas validitas dan rehabilitasinya. Dalam penelitian ini observasi dilakukan pada KPP Pratama Bireun. 


\section{Metode Analisis Data}

Metode analisis data yang digunakan dalam penelitian ini adalah metode deskriptif. Penelitian deskriptif adalah penelitian yang berusaha mendeskripsikan suatu gejala, peristiwa, kejadian yang terjadi sekarang ini. Melalui penelitian deskriptif, peneliti berusaha mendeskripsikan peristiwa dan kejadian yang menjadi pusat perhatian tanpa memberikan perlakuan khusus terhadap peristiwa tersebut.

Tahap-tahap analisis dalam penelitian ini

1. Mengumpulkan data dari artikeartikel yang memuat tentang sistem administrasi perpajakan modern terhadap efektivitas pelaksanaan pemeriksaan fungsional.

2. Menganalisis informasi yang didapatkan.

3. Evaluasi perubahan yang terjadi.

4. Memberikan kesimpulan dan saran.

\section{HASIL PENELITIAN}

\section{Gambaran Umum}

Modernisasi Direktorat Jenderal Pajak yang mulai diterapkan pada tahun 2007, Salah satunya dengan modernisasi KPP yang hingga saat ini telah mencapai kemajuan yang signifikan. Hampir semua KPP di Aceh saat ini telah menjadi KPP

Modern, dan hampir semua kabupaten telah memiliki kantor Pelayanan Pajak Pratama. Berdasarkan Peraturan Menteri Keuangan Republik Indonesia No.132/PMK.01/2006 tanggal 22 Desember 2006 tentang organisasi dan tata kerja Instansi Vertikal Direktorat Jenderal Pajak , Kantor Pelayanan Pajak (KPP) adalah instansi Vertikal Dirjen Pajak yang berada dibawah dan bertanggungjawab langsung kepada kepala kantor wilayah.

KPP Pratama Bireuen bertanggung jawab langsung kepada Kepala Kantor

Wilayah Aceh. Kantor Pelayanan Pajak Pratama Bireuen yang berdiri pada tanggal 9 september 2008. Kantor Pelayanan Pajak
Bumi Bangunan Lhokseumawe mengalami perubahan secara nasional menjadi kantor Pelayanan Pajak Pratama Bireuen yang berkedudukan di kota Lhokseumawe tepatnya di jalan T. Hamzah Bendahara, Lhokseumawe.

\section{Deskripsi Penelitian}

1. Sistem administrasi perpajakan modern KPP Pratama Bireuen sudah memiliki infrastruktur yang dapat mempermudah pelayanan wajib pajak. Dengan adanya sistem ini, wajib pajak dalam hal pemenuhan kewajiban perpajakannya dapat menghemat waktu dalam pelaksanaanya, serta pelayanan fungsional pemeriksa meningkat setelah diterapkannya sistem administrasi perpajakan modern.

2. Rasio fungsional pemeriksa dengan jumlah tugas yang diperiksa masih kurang banyak jika dibandingkan tuganya dalam melaksanakan pekerjaan tepat waktu. Tidak semua wajib pajak itu menyempaikan SPT- nya tepat waktu dikarenakan ada satu dan hal lainnya. Gambaran umum mengenai pemeriksaan terhadap wajib pajak guna meningkatkan kepatuhan wajib pajak, bagi wajib pajak yang melakukan kecurangan atau kesalahan dalam membayar pajak dan telat dalam menyampaikan SPT dapat dikenakan sanksi baik sanksi administrasi maupun sanksi pidana karena dengan sanksi tersebut pemerintah berharap wajib pajak akan patuh dalam memenuhi kewajibannya untuk membayar pajak sesuai dengan peraturan yang telah ditetapkan.

\section{PENUTUP}

\section{Kesimpulan}

Berdasarkan hasil penelitian dan pembahasan yang telah diuraikan penulis

Mengenai analisis sistem administrasi perpajakan modern terhadap efektivitas 
pelaksanaan pemeriksaan fungsional dan implikasinya pada kepatuhan wajib pajak maka penulis dapat mengambil kesimpulan sebagai berikut:

1. Sistem administrasi perpajakan modern terhadap kepatuhan wajib pajak melalui efektivitas pelaksanaan pemeriksaan fungsional pada KPP Pratama Bireuen mempunyai tujuan untuk mengetahui kepatuhan pemenuhan kewajiban perpajakannnya misalnya dalam SPT menunjukkan kelebihan pembayaran, SPT pajak penghasilan menunjukkan rugi, dan SPT tidak disampaikan atau disampaikan tidak tepat waktu. Dan juga untuk melaksanakan ketentuan perundangan perpajakan misalnya dalam pemberian nomor pokok wajib pajak(NPWP), penghapusan nomor pokok wajib pajak, dan pengukuhan atau pencabutan pengukuhan pengusaha kena pajak.

\section{Saran}

Berdasarkan hasil pembahasan dan kesimpulan mengenai analisis sistem administrasi perpajakan modern terhadap efektivitas pelaksanaan pemeriksaan fungsional dan implikasinya pada kepatuhan wajib, maka saran yang dapat dikemukakan sebagai berikut:

1. Bagi Peneliti Selanjutnya. Hasil yang dapat dipakai dalam penelitian ini dipergunakan sebagai bahan referensi bagi peneliti selanjutnya, dapat juga lebih memperluas cakupan variabel lain yang tidak terdapat dalam penelitian ini. Misalnya menambahkan variabel dependen lainnya. Alasan mengapa mengulas penelitian ini lebih dalam agar hasil yang didapat akan memberikan temuan-temuan baru yang berarti dan bermanfaat bagi pihak lainya.
2. Bagi Wajib Pajak di Kantor Pelayanan Pajak Pratama Bireuen. Meskipun Tahun Pembinaan Wajib Pajak telah berakhir dengan program kerja pemerintah dan telah memberikan dampak yang signifikan terhadap peningkatan kepatuhan wajib pajak. Maka diharapkan untuk kedepannya Wajib Pajak dapat patuh dan sadar akan kewajibannya tanpa perlu menunggu resposivitas para aparat pajak serta tidak ada lagi didapati kembali Wajib Pajak yang masih tidak patuh.

3. Bagi KPP Pratama Bireuen. Dengan menyediakan fasilitas pokok pajak yang dilaksanakan pada suzuya mall Bireuen, komplek perkantoran pemerintah kabupaten Bireuen membukaseluas-luasnya kepada wajib pajak untuk kemudahan dalam memperoleh informasi perpajakan dan tata cara pemenuhan kewajiban perpajakan yang disediakan oleh KPP Pratama Bireuen pada tahun ini sudah baik, tidak hanya itu disarankan untuk lebih meningkatkan sosialisasi mengenai program $e$-filling kepada wajib pajak yang selama ini tidak patuh dalam hal penyampaian SPT tahunannya. 


\section{KEPUSTAKAAN}

Aminah.2014. "Pengaruh penerapan

Sistem Administrasi

Perpajakan modern terhadap

Kepatuhan Wajib Pajak pada

KPP Pratama Kota Surakarta”.

Skripsi (dipublikasikan) Fakultas

Ekonomi dan Bisnis Universitas

Muhammadiyah, Surakarta.

Azis, Aiman Abdul. 2015. Pengaruh

kualitas pelayanan terhadap

kepatuhan wajib pajak.skripsi.

Dewi, Irra Chisyanti. 2011. Pengantar Ilmu

Administrasi, PT Prestasi

Pustakaraya. Jakarta.

Diana. 2013. "Konsep Dasar Perpajakan.

Bandung" : PT Refika Adimata.

Fasmi, Lasnofa dan Fauzan Misra. 2013. "Pengaruh Modernisasi Sistem Administrasi Perpajakan

Terhadap Tingkat Kepatuhan Pengusaha Kena Pajak Di Kantor Pelayanan Pajak (KPP) Pratama Padang". Simposium Nasional Akuntansi 15.

Gunadi. 2013. Panduan Komprehensif Pajak Penghasilan. Edisi 2013, Jakarta : Penerbit Bee Media Indonesia.

Irawan, Hasan dan Siti Khairani. 2013. "Pengaruh Sistem Administrasi Perpajakan Modern Terhadap Kepatuhan Wajib Pajak Pada Kantor Pelayanan Pajak Maya Palembang". Jurnal Akuntansi.

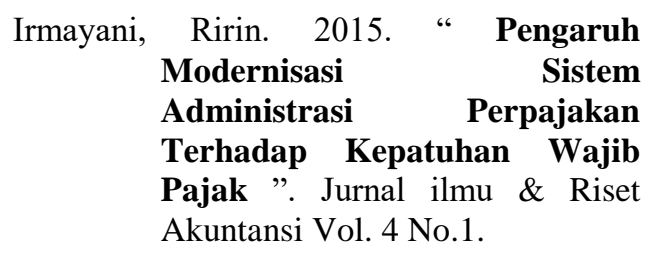

Mardiasmo. 2009. "Perpajakan Edisi Revisi 2009". Yogyakarta, Penerbit Andi.

Mardiasmo.2011. "Perpajakan Edisi Revisi 2011". Yogyakarta: Andi.
Mardiasmo.2013. "Perpajakan Edisi Revisi 2013". Yogyakarta: Andi.

Masri, I., \& D.Martani. (2012). Pengaruh Tax Avoidence Terhadap Cost of Debt. PPJK 20, Tesis Fakultas Ekonomi Universitas Indonesia, Jakarta.

Muljono, Djoko. 2010. "Hukum Pajak: Konsep, Aplikasi, dan Penuntun Praktis". Yogyakarta: Andi Offset.

Nazir. Mohammad, ph.D. (2011) Metode Penelitian. Jakarta : ghalia Indonesia.

Ni Luh Erawati. 2016. “ Pengaruh Sistem Administrasi Perpajakan Modern Terhadap Efektivitas Pelaksanaan Pemeriksaan Fungsional pada KPP Pratama Denpasar Timur ". Jurnal Akuntansi.

Oktaviani, R. M., dan 1. (2015). Determinan kepatuhan wajib pajak badan dengan niat sebagai pemediasi dari perspektif planned behaviour theory. Jurnal Bisnis dan Ekonomi (JBE), 22(1), 85-96.

Patsal,F (2012) "Pengaruh Sistem Administrasi Perpajakan Modern Terhadap Efektivitas Pelaksanaan Pemeriksaan Fungsional Pada KPP Pratama di wilayah Kota Makassar". Skripsi yang di publikasikan Fakultas Ekonomi dan Bisnis Universitas Hasanuddin Makassar.

Pohan, Chairil Anwar. 2016."Pedoman Lengkap Pajak Pertambahan Nilai. Teori, Konsep, dan Aplikasi PPN". PT. Gramedia Pustaka Utama. Jakarta. Gava Media. Yogyakarta.

Rahayu, Siti Kurnia dan Ely Suhayati. 2008. Pemeriksaan Pajak (Tax Audit). Bandung: Universitas Komputer Indonesia. 
Rahayu, Sri dan Ita Salsalina Lingga. 2009.”

Pengaruh Modernisasi Sistem

Administrasi Perpajakan

Terhadap Kepatuhan Wajib

Pajak". Jurnal Akuntansi Vol.1

No.2 November 2009: 119-138.

Rapina, Jerry dan Yenni Carolina. 2011. "Pengaruh Penerapan Sistem Administrasi Perpajakan Modern Terhadap Kepatuhan Wajib Pajak (Survey Terhadap Kantor Pelayanan Pajak Pratama Bandung Cibeunying)". Jurnal Riset Akuntansi Vol.III No.2 Oktober 2011.

Rahman, Abdul. 2011. Panduan Pelaksanaan Administrasi Perpajakan untuk Karyawan, Pelaku Bisnis dan Perusahaan. Bandung: Nuansa Cendikia.

Republik Indonesia. Undang-Undang No. 28 Tahun 2007 tentang Perubahan Ketiga atas Undangundang No. 6 tahun 1983 tentang Ketentuan Umum dan Tata Cara Perpajakan. Depkeu, Jakarta.

Suandy, Erly. 2006. "Perencanaan Pajak". Jakarta: Salemba Empat.

Sugiyono. (2007). Metode Penelitian Kuantitatif dan Kualitatif. Bandung : CV.Alfabeta

Sugiyono. (2011). Metode Penelitian Kuantitatif dan Kualitatif. Bandung : CV.Alfabeta

Suminarsasi, Wahyu, 2011. Pengaruh keadilan, sistem perpajakan, dan diskriminasi terhadap persepsi wajib pajak mengenai etika penggelapan pajak. Yogyakarta.

Suparman. 2007. "Sistem Administrasi Perpajakan Modern" (online), (http://pajaktaxes.blogspot.com/2 007/04/sistem-administrasiperpajakan-modern.html, diakses tanggal 17 september 2013).

Surat Edaran Direktur Jenderal pajak Nomor SE-10/PJ.7/2004 tentang Kriteria Pemeriksaan Rutin.

Suran Edaran Direktorat Jenderal Pajak SE19/PJ/2007 tentang Persiapan Penerapan Sistem Administrasi Perpajakan Modern pada Kantor Wilayah DJP dan Pembentukan Kantor Pelayanan Pajak Pratama di Seluruh Indonesia Tahun 2007-2008.

Undang-Undang No.16 Tahun 2000 Tentang Wajib Pajak.

Waluyo, dan Wiryawan B Ilyas. 2007. Perpajakan Indonesia. Jakarta: Salemba Empat

Widjaya, Annisa Gama. 2011.” Studi Evaluasi Kepatuhan Wajib Pajak Sebelum dan Sesudah Reformasi Perpajakan 2008 dan Implikasinya terhadap Penerimaan Pajak pada KPP Prataman Kota Semarang di Lingkungan Kantor Wilayah Direktorat Jenderal Pajak Jawa Tengah I'. Universitas Diponegoro. Semarang. Di akses di http: //eprints.undip.ac.id/27891/1/jur nal.pdf. (www.infopajak.com). (Http//:www.ortax.org) 